\title{
THE INFLUENCE OF LONG TERM SOUND STRESS ON HISTOLOGICAL STRUCTURE OF BROILER'S ADRENAL GLANDS
}

\section{D. Žikić ${ }^{1}$, G. Ušćebrka ${ }^{1}$, D. Gledić ${ }^{2}$, M. Lazarević ${ }^{2}$, S. Stojanović ${ }^{1}$, Z. Kanački $^{1}$}

${ }^{1}$ Faculty of Agriculture, 21000, Novi Sad, Republic of Serbia

${ }^{2}$ Faculty of Veterinary Medicine, 11000, Belgrade, Republic of Serbia

Corresponding autor: dragan.zikic@stocarstvo.edu.rs

Original scientific paper

\begin{abstract}
The aim of this paper is to examine the effect of different sound stress duration on adrenal gland of broiler chickens of different age. The experiments were conducted on 90 HYBRO broiler chickens, divided into nine groups (each group consisting of 10 birds) by different age and lenght of sound stress duration. The chickens were exposed to sound stress in sound attenuated building using a fire alarm bell $(95 \mathrm{~dB})$ for stress sessions lasted 120 min every day. The histological structure of adrenal gland was analyzed by light microscopy. The results indicate that adrenal gland is sensitive on this kind of stress and sound as stressor could introduce organism in stress reaction. Adrenal glands of broilers exposed to sound stress characterized by marked hyperemia, hypertrophy of interrenal cells, smaller affinity for staining of chromaffin cells compared with control groups. According to our results, degree of histological changes of adrenal gland under the influence of sound stress depends on the length of exposure and age of chickens.
\end{abstract}

Key words: sound stress, broiler chickens, adrenal gland

\section{Introduction}

Stress is the reaction of the organism to stimulus which disturbe physiological equilibrium, usually with harmful consequences. This disturbance of homeostasis results in changes in the concentration of large number of different hormones that have a crucial role in the regulation of immune system function.

There is experimental evidence that noise exposure may be a potential stressor in farm animal husbandry. Physiological and behavioural studies have identified noise stress during housing (Talling et al., 1998a; Schaffer et al., 2001), transport and at the abattoir (Geverink et al., 1998). Exposure to noise stress is 
known to activate the HPA axis in different species (Engeland et al., 1990; Van Raaij et al., 1997; Evans et al., 2001; Monsefi et al., 2006).

Noise as a stress factor in fowls has not yet been sufficiently investigated. According to Campo et al. (2005) noise seems to affect adversely the productive performance and behaviour of the birds. Stadelman (1958a) reported violent behavioural response in young chickens to intermittent sound exposure at 100-118 $\mathrm{dB}$. Sound intensities of $115 \mathrm{~dB}$ were effective in interrupting brooding in hens (Stadelman, 1958b). A significant negative effect of acute noise exposure at $80 \mathrm{~dB}$ and $100 \mathrm{~dB}$ on stressfulness in broilers was described by Chloupek et al. (2009), who found a significant increase in corticosterone and cholesterol levels after 10 min of noise exposure.

Changes in structure of adrenal gland in poultry, as results of influence of diffrent stressors, indicate that adrenal glands are involved in stress reaction (Nir et al., 1975; Carsia and Weber, 1986; Mahata et al., 1990, Cheng and Muir, 2004, Moneva et al., 2009).

The aim of our investigation was to estimate the influence of long term sound stress on adrenal gland morphology in broiler chickens.

\section{Materials and Methods}

The experiments were conducted on 90 HYBRO broiler chickens, divided into nine groups (each group consisting of 10 birds) as follows:

$\mathrm{C}_{1-15}$ - control (non exposed) group

$\mathrm{O}_{1-15}$ - chickens exposed to the sound stress from $1^{\text {st }}$ to $15^{\text {th }}$ day of life

$\mathrm{C}_{1-30}$ - control (non exposed) group

$\mathrm{O}_{1-30}$ - chickens exposed to the sound stress from $1^{\text {st }}$ to $30^{\text {th }}$ day of life

$\mathrm{O}_{15-30}$ - chickens exposed to the sound stress from $15^{\text {th }}$ to $30^{\text {th }}$ day of life

$\mathrm{C}_{1-45}$ - control (non exposed) group

$\mathrm{O}_{1-45}$ - chickens exposed to the sound stress from $1^{\text {st }}$ to $45^{\text {th }}$ day of life

$\mathrm{O}_{15-45}$ - chickens exposed to the sound stress from $15^{\text {th }}$ to $45^{\text {th }}$ day of life

$\mathrm{O}_{30-45}$ - chickens exposed to the sound stress from $30^{\text {th }}$ to $45^{\text {th }}$ day of life

The control and exposed chickens were kept in two different buildings under same conditions of temperature, light, humidity and number of birds per $\mathrm{m}^{2}$. They were fed ad libitum and had free access to water. According to the experimental schedule, chickens were moved from the building without noise to the building where they were subjected to sound stress. The chickens were exposed to sound stress in sound attenuated building using a fire alarm bell (95 dB) for stress sessions lasted $120 \mathrm{~min}$. every day. The bell was programmed to ring for 5 sec in a variable interval schedule (5 to $115 \mathrm{~s}$ ) through signals generated by PC software. Every 15 day, birds were sacrificed as show in above schedule. For histological investigation samples of adrenal glands were fixed in Bouin solution 
for $24 \mathrm{~h}$ and after standard histological procedure of dehydration organs are were embedded in paraffin. Serial cuts, $5 \mu \mathrm{m}$ thickness, were made by microtome and stained with hematoxyline and eosine. Histological analysis was performed with light microscope Leica DLMS connected with camera (Leica DC-300). Software for image analysis was IM 1000 (Leica Imaging Systems Ltd, Cambridge, UK).

\section{Results and Discussion}

In chickens, adrenal glands may be a single median structure or two separate organs, always in close contact with each other, next to the kidneys. The gland is surrounded by a loose connective capsule and in contrast to mammals, a distinct steroidogenic cortex and a chromaffin medulla are not present. Rather, clumps or strands of chromaffin cells are admixed with blood vessels and interrenal steroidogenic cords, radially arranged, both in the subcapsular zone and in the inner part of the gland

The typical changes of adrenal glands between control groups and groups of chicken exposed to sound stress were showed at figures 1-3.
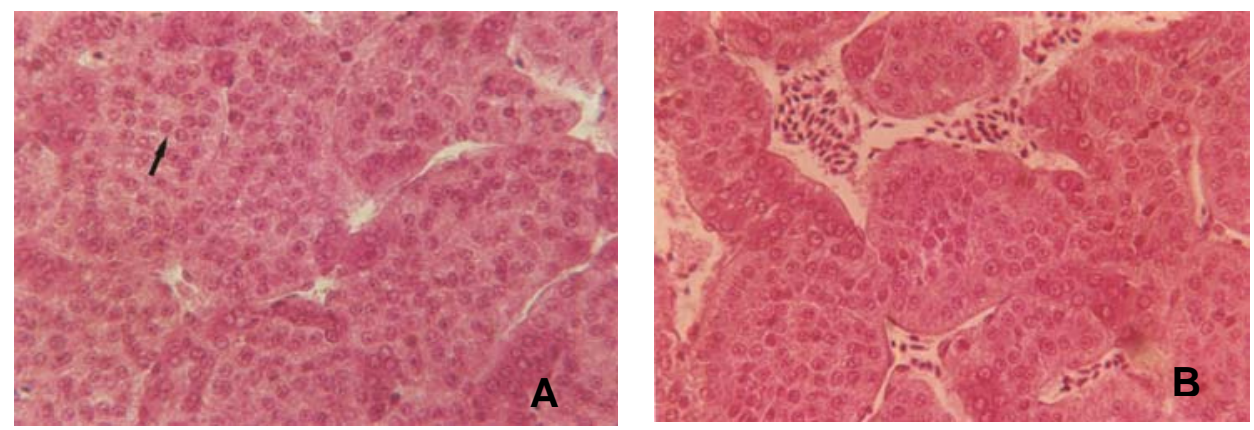

Figure 1. Microphotographs of chicken adrenal gland ( $\mathrm{A}$ - control group, 15 days old; $\mathrm{B}$ sound stress from 1st. to 15th days; arrow - interrenal cells (HE; 252x)

Adrenal glands of control group, 15th day old, heve clear diferentiation on interrenal and chromaffin cells, as well developed capillary network. Interrenal cells are grouped and with circular orientation as glomerul, while medulocites are localized near cappilary in formation of few cells (Figure 1A). In interrenal cells are evident good vacuolisation with significant lipid accumulation. In chickens exposed to sound stress at $15 \mathrm{t}$ day old, dilatation of blood vessels are marked (figure 1B). Interrenal cells of chickens exposured to sound stres from 1st to 15th day, characterized hyperthrophy with decreased vaculization and changes in cells size and shape. Chromaffin cells of exposed grupe have smaller afinity to staining then control group. 
At the age of 30th day, adrenal gland of chickens from control group characterized clear diferentitation on interenal and chromaffin cells. In that age, light interrenal cells are dominant, but compared with control group of 15 th day old, huge number of chromaffin cells exists (Figure 2A). In the group which was exposured to stress from 15th to 30th day, large number of dark interrenal, smaller diameter of cells and changes in nuclei, as well as individual very large light cells with merked vacuolization was observed (Figure 2B).
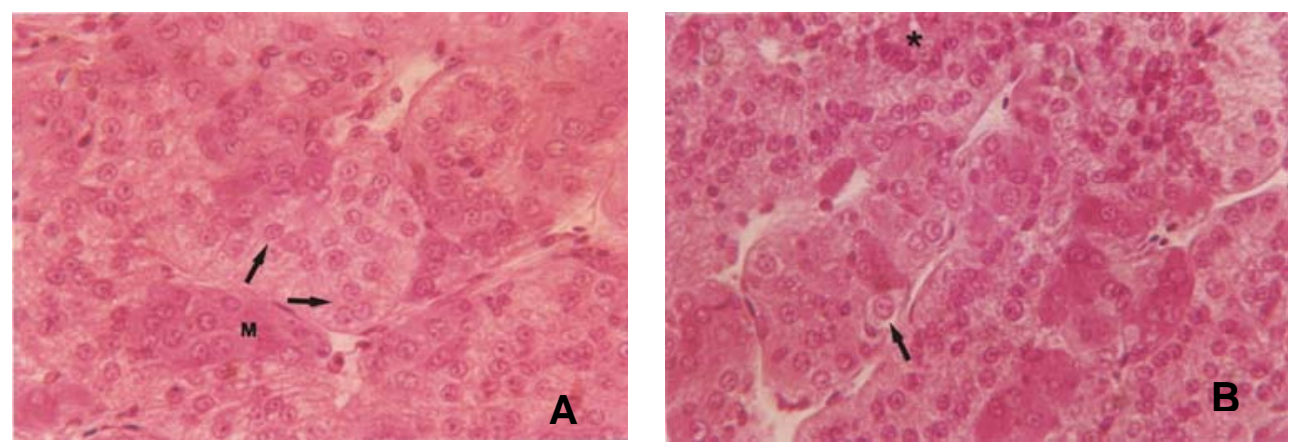

Figure 2. Microphotographs of chicken adrenal gland ( $\mathrm{A}$ - control group, 30 days old; $\mathrm{B}$ sound stress from 15 th to 30th days; arrow - light interrenal cells; * - dark interrenal cells; $M$ chromaffin cells $(\mathrm{HE} ; 400 x)$

The structure of adrenal gland of control group at 45th day of age is simular as in control groups at 15th and 30th day old chickens. In the group was exposured to stress from 15th to 45th days clear differet between light and dark interrenal cells. Light cellc are large with marked vacuolization, and dark are smaller, with less vacuoles and cytoplasm. At the chickens from that group large difference in diameter of cells and lagre number of cells with degenerative changes were visible (Figure 3).

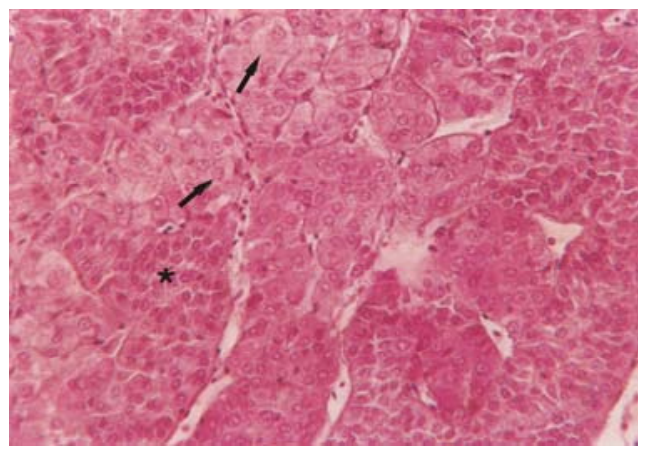

Figure 3. Microphotograph of chicken adrenal gland (sound stress from 15th to 45th days; arrow - light interrenal cells; * - dark interrenal cells (HE; 252x) 
The results presented in this paper indicate the stressful effects of noise, and considering that the study of histological structure of adrenal gland becomes more important. Degree of histological changes of adrenal gland under the influence of sound stress depends on the length of exposure and age of chickens. Results about level of corticosterone in broiler chickens exposured to sound, according with our results, point out on stres reaction (Bedanova et al., 2010). Also, our results (Lazarevic et al., 2000), showed that sound have significant influence on change heterophil/lymphocyte ratio, which is one of imoprtant indicator of avian stress reaction (McFarlane and Curtis, 1989). According with our result, adrenal glends of birds are known to respond to stress condition by interrenal hyperplasia (Garren and Barber, 1955; Siegel, 1959; Feeman, 1970; Aire, 1980) and changes in interrenal cord and interrenal and chromafine ratio (Sharma et al., 2009).

\title{
Conclusion
}

Chronic sound stress causing significant changes in histological structure of adrenal gland in broiler chickens. These changes are reflected as hyperemia and changes in interrenal cells and chromaffin cells. The typical changes were result of stressogenic effect of sound, and these reactions point out that those chickens were in stress reaction.

Degree of histological changes of adrenal gland under the influence of sound stress depends on the length of exposure and age of chickens.

\section{Uticaj dugotrajnog zvučnog stresa na histološku građu nadbubrežne žlezde brojlera}

\author{
D. Žikić, G. Ušćebrka, D. Gledić, M. Lazarević, S. Stojanović, Z. Kanački
}

\section{Rezime}

Cilj ovog rada je da ispita uticaj različite dužine trajanja zvučnog stresa na histološku građu nadbubrežnih žlezda brojlerskih pilića u različitim uzrastima. Ogled je izveden na 90 HYBRO brojlerskih pilića, podeljenih u 9 grupa u skladu sa uzrastom i dužinom izlaganja stresu. Pilići su zvučnom stresu bili izlagani u zvučno izolovanim objektima uz korišćenje požarnog alarmnog zvona (95dB) u trajanju od 120 min svakog dana. Histološka građa nadbubrežnih žlezda je analizirana svetlosnim mikroskopom. Rezultati ukazuju da je nadbubrežna žlezda osetljiva na ovu vrstu stresa i da zvuk, kao stresor, može da uvede organizam u stresnu reakciju. Nadbubrežne žlezde pilića izlaganih zvučnom stresu karakteriše 
značajna hiperemija, hipertrofija interrenalnih ćelija, manji afinitet prema bojenju hromafinih ćelija u odnosu na kontrolnu grupu. U skladu sa ovim rezultatima, stepen histoloških promena nadbubrežne žlezde pod uticajem zvučnog stresa zavisi i od dužine izlaganja i uzrasta pilića.

\section{References}

AIRE T.A. (1980): Morphometric study of the avian adrenal gland. J. Anat., 131, 1, 19-23.

BEDANOVA I., CHLOUPEK P., VOSMEROVA P, CHLOUPEK J, VECEREK V. (2010) Time course changes in selected biochemical stress indices in broilers exposed to short-term noise. Acta Vet. Brno, 79, S35-S40.

CAMPO J.L., GIL M.G., DAVILA S.G. (2005): Effects of specific noise and music stimuli on stress and fear levels of laying hens of several breeds. Appl. Anim. Behav. Sci., 91, 75-84.

CARSIA R.V., WEBER H. (1986): Genetic-dependent alterations in adrenal stress response and adrenocortical cell function of the domestic fowl (Gallus domesticus). Proc. Soc. Exp. Biol. Med., 183, 99-105.

CHENG H.W., MUIR W.M. (2004): Chronic social stress differentially regulates neuroendocrine responses in laying hens: II. Genetic basis of adrenal responses under three different social conditions. Psychoneuroendocrinology, 29, 961-971.

CHLOUPEK P., VOSLAROVA E., CHLOUPEK J., BEDANOVA I., PISTEKOVA V., VECEREK V. (2009): Stress in broiler chickens due to acute noise exposure. Acta Vet. Brno, 78, 93-98.

ENGELAND W.C., MILLAR P., GANN D.S. (1990): Pituitary-adrenal and adrenomedullary responses to noise in awake dogs. Am. J.Physiol., 258, R672R677.

EVANS G.W., LERCHER P., MEIS M., ISING H., KOFLER W.W. (2001): Community noise exposure and stress in children. J. Acoust. Soc. Am., 109, 10231027.

FREEMAN B. M. (1970): The effect of adrenocorticotrophic hormone on adrenal weight and adrenal ascorbic acid in normal and bursectomised fowl. Comparative Biochemistry and Physiology, 32, 755-761.

GARREN H.W., BARBER, C.W. (1955): Endocrine and lymphatic gland changes occurring in young chickens with fowl typhoid. Poult. Sci., 34, 1250-1258.

GEVERINK N.A., BQHNEMANN A., VAN DE BURGWAL J.A., LAMBOOIJ E., BLOKHUIS H.J., WIEGANT V.M. (1998): Responses of slaughter pigs to transport and lairage sounds. Physiol. Behav. 63, 667-673.

LAZAREVIC M., ZIKIC D., USCEBRKA G. (2000): The influence of long term sound stress on the blood leukocyte count, heterophil/lymphocyte ratio and 
cutaneous basophil hypersensitive reaction to phytohemagglutinin in broiler chickens. Acta Vet -Beograd, 50, 63-76

MAHATA S.K., DE M., PAL D., GHOSH A. (1990): Effect of stress on the catecholamine content of the adrenal gland of intact and bursectomized chicks. Clin. Exp. Pharmacol. Physiol., 17, 805-808.

McFARLANE J.M, CURTIS S.E. (1989): Multiple concurrent stressors in chicks. 3. Effects on plasma corticosterone and the heterophil:lymphocyte ratio. Poult. Sci., 68, 522-527.

MONEVA P., POPOVA-RALCHEVA S., ABADJIEVA D., GUDEV D., SREDKOVA V. (2009) Poultry welfare assessment; is it possible to avoid handling-induced mental stress interference? Biotechnology in Animal Husbandry, 25, 5-6, 1055-1062.

MONSEFI M., BAHODDINI A., NAZEMI S., DEHGHANI G.A. (2006) Effects of noise exposure on the volume of adrenal gland and serum levels of cortisol in rat. Iran J. Med. Sci. March, 31, 1, 5-8.

NIR I., YAM D., PEREK M. (1975) Effects of stress on the corticosterone content of the blood plasma and adrenal gland of intact and bursectomized Gallus Domesticus. Poult. Sci., 544, 2101-2110.

SCHAFFER D., MARQUARDT V., MARX G., VON BORELL E. (2001): Noise in animal housing-a review with emphasis on pig housing. Dtsch. Tierrztl. Wochenschr., 108, 60-66.

SIEGEL H. S. (1959): The relation between crowding and weight of adrenal glands in chickens. Ecology, 40, 495-498.

SHARMA D, CORNETT L.E, CHATURVEDI C.M. (2009): Osmotic stress induced alteration in the expression of arginine vasotocin receptor VT2 in the pituitary gland and adrenal function of domestic fowl. General and Comparative Endocrinology, 160, 216-222.

STADELMAN W.J. (1958a): Observations with growing chickens on the effects of sounds of varying intensities. Poult. Sci., 37, 776-779.

STADELMAN W.J. (1958b): The effect of sounds of varying intensity on hatchability of chicken eggs. Poult. Sci., 37, 166-169.

TALLING J.C., LINES, J.A., WATHES, C.M., WARAN, N.K. (1998): The acoustic environment of the domestic pig. J. Agric. Eng. Res., 71, 1-12.

VAN RAAIJ M.T.M., DOBBE C.J.G., ELVERS B., TIMMERMAN A., SCHENK E., OORTIGIESEN M., WIEGANT, V.M. (1997): Hormonal status and the neuroendocrine response to a novel heterotypic stressor involving subchronic noise exposure. Neuroendocrinology, 65, 200-209. 